\title{
DIE EVALUERING VAN VERPLEGING IN SUID-AFRIKA
}

\author{
Hettie Steenberg, B.Cur. (I. et A.) 3 \\ Universiteit van Port Elizabeth
}

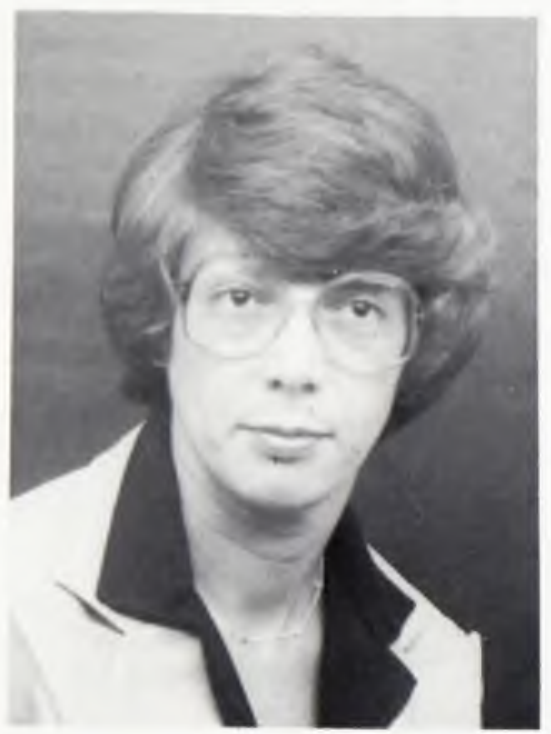

\section{SUMMARY}

In any institution there must be a system of evaluation but it is important to remember that evaluation will be useless unless it follows careful planning.

Planning gives direction for action.

The planning process includes formulation of an objective towards which purposeful action, to the best of nursing ability, will be directed.

Whenever a specific nursing procedure is decided on, provision must at the planning stage be made for continuous testing of the effectivity of the procedure in terms of predetermined objectives which the specific procedure is required to reach. These objectives will serve as the established criteria for evaluation.

\section{INLEIDING}

7 VALUERING is nie "n begrip waaroor daar vinnig A heen beweeg kan word nie, trouens daar is onnoembare volumes vol geskryf oor evaluering. Aangesien die begrip in die loop van hierdie aanbieding ook mettertyd meer breedvoerig omskryf gaan word, sal daar ter inleiding net baie kortliks volstaan word met ' $n$ verduideliking soos wat Elda S. Popiel dit sien: "Evaluation is an integral part of life itself. It is the process by which we make judgements about what we observe and perceive in relation to our objectives or goals." ". . . evaluation is a continuous guide tow ard action or further action." (l.p.175).

As evaluering as sulks 'n omvattende verskynsel is, sal gevind word dat evaluering van verpleging 'n "gekompliseerde omvattendheid" is. Omdat verpleging sy eie unieke versorgingsterrein het, sal die evaluering daarvan nood- wendig ook ontwikkel in 'n eiesoortige aard. Verpleging in al sy fasette bly 'n verskynsel wat moeilik gedefinieer kan word. ' $n$ Definisie wat in 1943 die lig gesien het en wat sedertdien baie aangehaal is, is die een van Suster Olivia Gowan. Sy sien verpleging as "n "art and science involving the total patient: promoting spiritual, mental, and physical health: stressing health education and health preservation: ministering to sick: caring for the patient's environment: giving health service to the family, the community and the individual.'" (2, p. 11).

Dit behoort nou reeds duidelik te wees dat dit twee omvattende aangeleenthede is wat hier ter sprake is. Wanneer evaluering van verpleging op 'n nasionale vlak plaasvind, poog dit om ' $n$ eenvormige oorkoepelende stelsel daar te stel wat sal lei tot uitbreiding van 'n uniforme stan'daard van dienslewering. Omdat Suid-Afrika 'n uniale staat is, is dit nie 
'n probleem om evaluering op makrovlak te ontwerp nie. Met die nodige kontrole vanuit die makrovlak is dit moontlik om die verloop op mikrovlak te reguleer

Soos wat die geskiedenis van verpleging deur die jare in Suid-Afrika ontplooi het, het evaluering van verpleging ook begin om ' $n$ belangrike faset van verpleging te word. Verpleging in Suid-Afrika het gegroei van die baanbrekerswerk deur mense soos Suster Henrietta. Suster Mary Agatha, Suster Helen Bowden, Emily Hobhouse en talle ander, tot wat dit vandag is te midde van al die snelle sosiale, wetenskaplike, ekonomiese en tegnologiese ontwikkelinge.

Verandering is aan die orde van die dag. Dit vind in cî̀ om verpleging plaas. Om te verseker dat daar "n rasionele verloop van sake plaasvind, is evaluering nodig. Indien daar veranderinge op die verpleegkundige terrein plaasvind, kan dit egter nie altyd gesien word as die positiewe uitvloeisel van evaluering nie. Veranderinge word soms aangebring sonder dat dit voorafgegaan is deur in program van evaluering. Wanneer veranderinge aangebring word in antwoord op evaluering of by wyse van eksperimentering, is hierdie veranderinge juis baie meer streng aan evaluering onderworpe.

\section{OMSKRYWING VAN EVALUERING}

In hierdie deel sal daar net gelet word op fasette van die begrip evaluering. Die omvang daarvan en metodes waarvan gebruik gemaak kan word, sal mettertyd volg.

Ten aanvang van hierdie deel kan ons met Prof. Rines (3.p.7) saamstem dat persone wat enige tegniek van evaluering toepas, moet weet wat evaluering is, wat die beginsels van evaluering is en wat die doel is wat met evaluering bereik wil word.

Heel tereg sien sy evaluering meer as net 'n tegniek en wel as 'n metode wat gebruik kan word om te bepaal tot watter mate die student (in hierdie spesifieke geval) die doelwit bereik het. As evaluering as ' $n$ proses gesien word behels dit 'n aantal stappe en ook 'n aantal verskillende maniere waarop daar na die persoon wat ge-evalueer word, gelet moet word. Evaluering is meer as toets en meet.

Om evaluering te kan implementeer is dit nodig om insig te he sover dit die beginsels van evaluering aangaan. Die volgende beginsels is van groot belang.

Ten eerste kan daar gelet word op die beginsel soos Prof. Rines (3, p.9) dit sien: (vry vertaling)

1 Evaluering moet in terme van die doelstellings gesien word. In hierdie geval het dit te doen met opvoedingsprogramme. Die doelwitte van die program kan dien as kriteria waarvolgens die student ge-evalueer kan word. Die volgende aanhaling stel die saak duidelik:

"One such set of objectives, designed for a course in fundamentals of nursing is to:

(1) be able to plan, give, and evaluate those nursing skills which are common throughout the field of nursing.

(2) understand her role as a nurse, as well as the roles of all other personnel, and be able to work with each effectively.

(3) help the patient and family understand and adjust to his illness.

(4) learn that nursing care of an ill person is an adapta- tion of the needs of a well person.

understand the role of the hospital as a community health agency."

2 Evaluering moet in terme van observasie van studente gedrag wees. Verwagte gedrag moel gedefinieer word en dan moet daar observasie gedoen word om te sien of studente daaraan voldoen.

3 Evaluering moet plaasvind met inagneming van die gedrag wat vir daardie betrokke stadium wat die student bereik het, behoorlik is. Gedrag moet dus nie net in terme van bereiking van die doelwitte van die program gesien word nie. maar ook in terme van die vlak van gedrag wat op in spesifieke stadium deur die student bereik behoort te word

+ Evaluering moet in voortdurende proses wees. Die implikasic hiervan is dat evaluering reeds in die vroee fases van die opvoedingsprogram moet begin en dat dit dan regdeur gevoer moet word. Dit impliseer verder dat enige student herhaaldelik ge-evalueer moet word.

5 Evaluering moet die stadium van groei en ontwikkeling wat die student bereik het, in ag neem. Dit is belangrik dat die student se intellektuele en emosionele ontwikkelingsvlak in ag geneem sal word tydens evaluering.

6 Evaluering moet almal wat deel het aan die opvoedkundige program insluit. Indien bv. die dosente slegs op haar eie evaluering steun vir ' $n$ beeld van die student, sal dit 'n eensydige mening weergee.

7 Evaluering behoort as stimulering vir verbetering van leergebeure te dien. Hierdie beginsel lê in die kerngedagte van die doel van evaluering en in die rede waarom evaluering gedoen word. Studente moet verbeter, groei en ontwikkel en dit is dan ook die primêre doel sowel as die primêre resultaat van evaluering.

8 Evaluering van gedrag moet in terme van behoorlike eenhede gemeet word.

Dit dan sover dit Prof. Rines se siening omtrent beginsels van evaluering aangaan. Daar kan vervolgens kortliks gelet word op hoe William $R$. Tracey die beginsels van evaluering sien: $(5$, p. 14)

"To be effective, evaluation of training and development must be conducted in such a way that it is consistent with the purposes, objectives. and goals of the training activity and is in accordance with accepted and proven principles of evaluation:

1 Evaluation must be conducted in terms of purposes

2 Evaluation must be co-operative. A one-man evaluation is little better than no evaluation.

3 Evaluation must be continuous.

4 Evaluation must be specific.

5 Evaluation must provide the means and focus for trainers to be able to appraise themselves, their practices, and their products.

6 Evaluation must be based on uniform and objective methods and standards."

Dit is net "n baie koit oorsig van hierdie beginsels, want tot 'n groot mate spreek hulle vanself.

Om te sê dat evaluering belangrik en selfs noodsaaklik is, 
is nie genoeg nie. Evaluering het 'n spesifieke doel in die hele opset waarin dit as 'n verskynsel toegepas word. Ter verduideliking van die doel van evaluering, steun ons ten aanvang weer op Prof. Rines se siening. Soos wat sy dit stel het dit betrekking op die opvoedkundige situasie. maar dit kan deur die leser verwerk word tot enige komponent wat binne die verplegingsterrein gevind kan word (soos wat dit gestel word in die volgende deel).

Die doelstellings word dan ook net kortliks aangestip: (3.p. 19).

1 Bepaal die vordering van die student ten einde die doel van die program te bereik.

2 Help die indiwiduele student om die sterk punte vol te hou en om die swakkes uit te skakel.

3 Help die dosente om haar onderrig te verbeter.

4 Bepaal die waarde van die onderneming in die algemeen.

5 Gee verklaring en definisie van die opvoedingsdoelstellings.

6 Ontwikkel meer betroubare instrumente vir evaluering.

7 Motiveer die studente.

8 Voorsien sielkundige sekuriteit aan die studente, personeel en gemeenskap.

9 Voorsien sekere voorskrifte om wetlike vereistes na te kom.

Aansluitend hierby kan daar ook gelet word op wat Barbara Stevens sien as die doel van evaluering. (4. p.214). Sy verwys na 'n lys wat deur Morgan saamgestel is:

1 "Determine how near individual students and the class as a whole come to reaching the goal.

2 Measure the rate of progress at any given time (toward the goal).

3 Determine effectiveness of the teaching materials, methods and activities.

4 Provide information useful to students, teachers and the public.

Other purposes that could be included are:

1 Aid administration in evaluating teachers for promotion.

2 Help the student maintain own strengths and eliminate weaknesses.

3 Provide information for students selecting elective courses.

4 Stimulate student thought regarding the course and its objectives.

5 Provide certification for licensure

6 Determine the worth of the undertaking in general."

Vir Tracey (5, p. 12) is dit ook belangrik dat daar wel evaluering sal wees en veral omdat evaluering " $n$ bepalende faktor kan wees ten opsigte van die waarde van opleiding en ten opsigte van die ontwikkeling van programme. Kortliks glo hy dat evaluering kan bepaal of tyd, energie en geld aangewend word om die regte resultate te toon. Evaluering voorsien veral in drie opsigte: Dit verseker dat daar gepoog sal word om te groei en te ontwikkel en uiteindelik by doelwitbereiking uit te kom. Verder verseker dit dat daar gelet sal word op effektiwiteit van optrede en laastens verseker dit 'n beginselpunt vir die ontwerp van 'n verbeterde program.

Voordat daar van die doel van evaluering afgestap word kan daar net baie kortliks ook gelet word op die siening van
E. Olivia Bevis: (8, p.136). Alhoewel dit ook hoofsaaklik gaan oor studentevordering, kan die doelstellings wat gestel word weer eens oorgeplaas word op ander terreine in die verpleegkunde.

"Evaluation of student progress is done for four basic purposes:

1 To determine student attainment of the behaviours estaolished as objectives.

2 To assess the success of the instructional delivery system and all of its components.

3 To predict professional success. for examole, with state boards and in the work world.

4 To determine grades. Grading is done to provide the learner and others insights into his achievement either in relation to the course goals or in comparison with peers."

Dit dan sover daar bespiegel sal word aangaande die redes vir evaluering.

Evaluering kan op verskillende maniere aangepak word afhangende van omstandighede soos wat dit in die verskil. lende komponente van die verpleegkundige terrein sal presenteer. Metodes van evaluering sal dan vlugtig aangeraak word wanneer die verskillende komponente in die volgende deel bespreek word.

Soos op talle terreine of suos in verband met talle ondernemings, is evaluering ook onderhewig aan probleme waarmee dit te kampe het. Personeel werk soms teen 'n hoë tempo om die daargestelde program afgehandel te kry en sien nie kans om van tyd tot tyd stil te staan en die saak in oënskou te neem nie. Die tydfaktor en die personeelsterkte is baie aktuele probleme. Dit is nie in alle gevalle te wyte aan swak entoesiasme nie, maar dit kan 'n daadwerklike tyd.en personeeltekort wees.

'n Ander tipe probleem wat kan voorkom is wanneer 'n evalueringsisteem gebruik word wat glad nie geskik is vir die spesifieke omstandighede van die verpleegkunde nie. Elke betrokke terrein behoort sy eie stelsel van evaluering te ont werp en slegs daardie items wat wel toepaslik is behoort uit ander stelsels oorgeneem te word.

'n Probleem wat ook heelwat probleme tot gevolg kan hê, is die verskynsel waar sommige owerhede of sommige lede van die personeel nie hul samewerking vir so 'n onderneming wil gee nie. Dit kan voortspruit uit gebrek aan insig maar ook uit ' $\mathrm{n}$ gevoel van bedreiging wat sommige mense ondervind wanneer hulle onderwerp word aan 'n stelsel van evaluering.

Om 'n suksesvolle sisteem van evaluering in te voer, sal dit nodig wees om alle probleemsituasies uit te sorteer en om dan met ' $n$ filosofie van daadwerklike optrede te begin. Om evaluering te laat groei tot 'n suksesvolle onderneming, stel Tracey $(5$, p. 18$)$ in die volgende items voor:

"The project must have the complete and unconditional backing of the top executive of the enterprise

Highly skilled personnel must be identified ana placed in positions where their talents can be fully exploited.

All personnel of the training and development activity must be directly involved.

Communication and co-ordination are essential

Evaluation must be conducted through the established organisation.

Realistic targets must be set for each phase of the 
evaluation.

Project personnel must be encouraged to meet regularly face to face to share ideas and thinking.

The training manager must insist that all studies be complete, detailed, and objective.

Continuous feedback relating to progress and problems must be provided regularly for staff and faculty as well as top management."

Met die afgelope deel is daar net gepoog om in baie kortlike omskrywing van evaluering te gee. Daar sal nietemin algaande nog meer duidelikhede omtrent evaluering na vore kom.

\section{OMVANG VAN EVALUERING}

In hierdie deel sal daar slegs gelet word op die omvangryke terrein in verpleging waarbinne die begrip van evaluering funksioneer.

Effektiewe evaluering moet spesifiek wees. 'n Vae, algemene toepassing van een of ander evalueringsmetode op etlike terreine binne die verpleging, sal weinig sukses hê. Die veld van verpleging is omvattend en uit verskeie komponente opgebou en daarom sal daar ook 'n omvattende program met verskeie komponente moet bestaan sover dit evaluering aangaan. Die wye omvang van verpleging kan onder drie hoofde geklassifiseer word, naamlik, pasiëntesorg, administrasie en opvoedkunde. Dit is die hoofkomponente wat dan weer onderverdeel kan word. Ten opsigte van elke sub-komponent moet daar " $n$ evalueringsbenadering en metode wees. Daar kan vervolgens gelet word op die verskeie komponente en die evaluering wat daarmee saamgaan:

\section{Opvoedkunde}

Opvoedkunde kan gesien word as daardie komponent van die verpleegkunde wat moet voorsien in die uitbreiding van kennis en vaardighede. Daar is tans 'n kennisontploffing aan die orde van die dag. Hierdie situasie het ook grootliks "n invloed op die verpleegkunde omdat verpleegkunde ' $n$ integrale deel van die samelewing uitmaak. Die mens is van die bydrae van die verpleegkundige terrein afhanklik vir die behoud van sy goeie gesondheid. Dit plaas dus "n verantwoordelikheid op die verpleegkundiges om 'n realistiese benadering te volg ten opsigte van die hantering van die kennis wat opgedoen word. Dit is dan ook so dat die verpleegkunde self ook 'n belangrike bydrae lewer tot die byvoeging van kennis tot hierdie algemene kennisontploffing.

Daar moet egter selektief te werk gegaan word in die benutting van kennis. Uitbreiding van kennis en vaardighede spruit uit die korrekte benutting van dit wat reeds bestaan. Deur dus 'n effektiewe stelsel van evaluering te hê, sal die verpleegkunde kan bepaal of kennis en vaardighede op 'n rasioneel verantwoordbare wyse bekom en uitgebrei word.

Op verpleegkundige terrein kan daar drie opvoedkundige subkomponente onderskei word, te wete: basiese opleiding, indiensopleiding en voortgesette opleiding. Daar kan net kortliks volstaan word met ' $n$ relatief kort definisie van elk:

\section{a) Basiese Opleiding}

Met basiese opleiding in verpleging word bedoel daardie opleiding wat aan persone gegee word wat pas tot die terrein toegetree het en wat dan op grond van toetredevereistes een of ander kategorie van opleiding sal ontvang. Die kursusse wat as basies gesien kan word is onder andere:

(i) Die kursus vir inskrywing as verpleegassistent

(ii) Die kursus vir inskrywing as verpleegkundige

(iii) Die kursus vir registrasie as verpleegkundige ens.
In die geval van die registrasie na "n basiese kursus, kan studente voortgaan met studie.

b) Voortgesette opleiding

Voortgesette opleiding kan gesien word as daardie opleiding wat deurloop word nadat 'n basiese opleidingsprogram voltooi is sodat kennis, vaardighede en ingesteldhede kan uitbrei ten einde beter gesondheidsdienste daar te stel. Daar is "n groot verskeidenheid van metodes waarvolgens voortgesette opleiding deurloop kan word.

c) Indiensopleiding

Indiensopleiding kan gesien word as daardie opleiding wat die werkgewer op ' $n$ beplande wyse gee aan alle kategorieë van verplegingspersoneel (in hierdie geval). Dit word ontwerp om in spesifieke behoeftes te voorsien en poog om personeel te alle tye op hoogte te hou van dit wat van hulle verwag word om te weet en te doen. Dit het " $\mathrm{n}$ besondere voordeel omdat dit 'n deurlopende proses is en omdat dit personeel voortdurend in kontak hou met die nuutste ontwikkelinge.

Dit dan is kortliks die subkomponente op die verplegingsopvoedkundige terrein. Die terrein van die opvoedkunde in verpleging bestaan uit 'n kliniese en teoretiese deel. Evaluering sal dus ietwat verskillend aangepak moet word alhoewel daar tog baie basiese punte van ooreenstemming sal wees. Om die volle omvang van evaluering op die opvoedkundige terrein binne die verpleegkunde te besef kan die volgende net kortliks genoem word:

- vir beide die teoretiese en die praktiese opleiding moet daar doelstellings geformuleer word. Hierdie doelstellings moet bereik word, maar hoe weet ons dat die doelstellings wat nagestreef word noodwendig die korrekte is? Doelstellings is dus voortdurend onderhewig aan evaluering, met ander woorde daar moet van tyd tot tyd stilgestaan word om te sien of doelstellings nog beantwoord aan die behoeftes en verwagtinge wat mense daarstel vir hul gesondheid.

- vir beide die teoretiese en die praktiese opleiding moet daar 'n leerplan wees waarvolgens opgetree word. 'n Leerplan moet in verhouding wees met doelstellings. Verander doelstellings dan moet die leerplan verander. Dit is egter nodig dat "n leerplan van tyd tot tyd aan evaluering onderworpe moet wees om te sien of dit nog poog om daargestelde doelstellings te bereik.

- vir beide die teoretiese en die praktiese opleiding bestaan daar ' $n$ wye reeks van metodes wat gevolg kan word. Metodes verander voortdurend as gevolg van mediese en tegnologiese sowel. as opvoedkundige veranderinge. Daar moet nie vasgesteek word by sommige metodes nie, maar daar moet ook nie roekeloos en ongeordend gespekuleer word met metodes nie. Metodes moet steeds so ingespan word dat dit beantwoord aan die vereistes van die leerplan sowel as aan die bereiking van die doelstellings van die opleiding. Om dit te verseker is evaluering nodig.

- vir beide die teoretiese en die praktiese opleiding is daar 'n administratiewe program nodig om die prosesse te laat voortgaan. Daar is personeel en hulpmiddels nodig om die voorgenoemde fasette doeltreffend te laat verloop. Om absolute doeltreffendheid te verseker is dit ook nodig om al die betrokke prosesse in die administrering van opleiding te onderwerp aan evaluering.

Om die bespreking van opvoedkunde af te sluit kan daar gelet word op metodes van evaluering wat op die opvoed- 
kundige terrein gebruik kan word:

\section{Evaluering van teoretiese kennis}

- beoordeling van gevallestudies en ander stukke wat op indiwiduele basis gelewer word. Die werk word gemeet volgens " $n$ daargestelde raamwerk wat "n uiteensetting gee van die doelstellings wat deur die student bereik moet word in die uitvoer van die opdrag.

- beoordeling van feitlike kennis kan geskied deur die skryf van "n toets of eksamen of deur die aflê van 'n mondelike toetsing. Die werk word gemeet volgens "n memorandum wat bepaal wat die algemene en spesifieke doelstellings was wat die student moes bereik deur die betrokke stuk werk te leer.

beoordeling van die student se insig op " $n$ gegewe tyd en gegewe plek wat bereik word in die leerplan.

\section{Evaluering van praktiese vaardighede}

- beoordeling van die student (of persoon) se vermoë om in opdrag uit te voer nadat die persoon bewys gelewer het dat sy die opdrag begryp en indien dit moontlik is vir die persoon om die opdrag uit te voer omdat daar voldoende fisiese fasiliteite is.

- beoordeling van ' $n$ persoon se vermoë om in 'n onbekende situasie op te tree en met een of ander mate van sukses die doel van die spesifieke opdrag te bereik.

- beoordeling van prosedures (die uitvoer daarvan en die noodsaaklikheid daarvan) volgens 'n stelsel van voortdurende meting binne die perke van die doelstellings van die leerplan

\section{Administrasie}

Die komponent van administrasie speel in belangrike rol in verpleging. Dit is veel meer as wat kortliks in die vorige paragraaf genoem is. Verpleging het ' $n$ oorkoepelende doelstelling wat alleenlik bereik kan word as die administrering van al die fasette van verpleging korrek verloop. Om te weet of dit korrek verloop moet daar 'n stelsel van evaluering bestaan ten opsigte van al die prosesse binne die administrering van verpleging. Die oorkoepelende administrering sluit opvoedkunde, pasiëntesorg sowel as administrasiefunksies in. Daar moet korrelasie wees tussen die administrasie van die drie komponente om te verseker dat die oorkoepelende doelstelling bereik word deurdat elke komponent sy bydrae lewer. Hierdie skakeling is slegs moontlik indien evaluering plaasvind van dit wat in die komponent plaasvind en as die resultate gesien word in die lig van die resultate van die komponente en met betrekking tot die doelstelling.

Die omvang van hierdie komponent is baie groot en vereis ook spesifieke evaluering vir elke proses in die komponent. Alhoewel die prosesse ' $n$ eenheid vorm en mekaar te alle tye sterk beïnloed. sal evaluering nogtans verskil ten opsigte van die prosesse binne die komponent van administrasie. Daar kan net kortliks gelet word op wat die prosesse is:

a) Beleid

Dit is die basiese beginprosesse wat deurloop moet word vir die identifisering en bepaling van doelwitte wat met die funksionele bedrywighede bereik wil word.

b) Organisering

Dit is die ordelike rangskikking van die indiwidue as enkelinge of in " $n$ groep in " $n$ bepaalde patroon sodat hul optrede in ' $\mathrm{n}$ bepaalde rigting gestuur kan word om 'n doelwit te bereik.

c) Personeel

Dit is die verkryging, benutting en instandhouding van menslike bronne vir die verrigting van funksionele bedrywighede vir die bereiking van die daargestelde doelwitte.

\section{d) Finansies}

Dit is die verkryging, bewaring en toewysing van geldelike bronne (voorrade) om "n doelwit te verwesenlik.

e) Prosedures

Dit is die ontwerp en ingebruikneming van prosedures en metodes sodat die doelwit op die doeltreffendste manier bereik kan word.

\section{f) Beheer}

Dit is die proses van kontrole volgens 'n bepaalde maatstaf van voorskrif en dan ' $n$ proses van verantwoordingdoening deur rekenskap te doen ten opsigte van handelinge.

Hierdie definisies word slegs gegee om aan te toon wat die inhoud van die komponent van administrasie behels. As hierdie prosesse ontleed sou word. sal dit baie duidelik blyk dat gereelde evaluering van elk van die prosesse noodsaaklik is.

Ter afsluiting van hierdie komponent kan daar ook net baie kortliks gelet word op "n paar metodes van evaluering wat op die terrein van die administrasie gebruik kan word:

- $n$ beleid omskryf die doelwit. As die doelwit nie bereik word nie is daar baie fasette wat ondersoek moet word. Die gesindheid van mense is " $n$ goeie maatstaf om te sien of die beleid ten opsigte van verpleging, bv., nog aanvaarbaar is. Evaluering bestaan dus uit: besluite of doelwitte wat in die beleid vervat is wel bereik is. Statistiese data sowel as openbare mening dien as evalueringsmetodes.

- die evaluering van organisering sal basies daarop neerkom dat nagegaan sal word of mense op die gegewe tye op gegewe plekke besig is met gegewe take wat gerig is op doelwitbereiking. Dit word gemeet na die hand van voorafopgestelde programme en as daar afwykings is beteken dit dat organisering nie meer effektief is nie en dat aanpassings gemaak moet word.

- personeelevaluering kan begin deur te let op wat die terugvoer ten opsigte van werwing is. Verder kan staatgemaak word op verslae om te sien wat personeel se aanpassing en produktiwiteit is ten einde te bepaal of daar effektiewe optrede is wat sal lei tot doelwitbereiking. Personeel se afwesigheid, klagtes, bedankings ens. kan alles dien as kriteria waarvolgens die evaluering van personeelaangeleenthede geloots kan word.

- evaluering van die effektiewe benutting van finansies sal weerspieël word in die finansiële verslae. Die effektiewe benutting van toerusting en voorrade kan waargeneem word in afdelings. Dit kan na vore kom uit die rekords van instandhouding, bv. rekords van herstel en afkeuring.

- die effektiewiteit van metodes en prosedures kan evalueer word tydens opnames of waarnemings gedurende die doen van prosedures of tydens die studie van werkstudiepersoneel. Die feit dat beplande funksies nie binne bepaalde tye afgehandel word nie kan ook ' $n$ aanduiding wees van tekortkominge in die persoon of in die uiteensetting van die prosedure.

- om seker te maak of metodes van beheer nog effektief is, sal 'n algehele evaluering van die totale sisteem gedoen moet word. Indien kontrole en verantwoordingdoening effektief is sal die doelwit van die instelling bereik word mits al die ander prosesse ook effektief verloop.

Dit was dan ook slegs 'n oppervlakkige siening van wat evaluering op die terrein van die administrasie kan inhou. 


\section{Pasiëntesorg}

Vanweë die klemverskuiwing ten opsigte van gesondheid, het gesondheidsclienste grootliks verander. Dit bring mee dat daar in die af gelope tyd heelwat veranderinge was ten opsigte van metodes van pasiëntesorg. Pasiëntesorg het al hoe meer gemeenskapsgeoriënteerd geword. As daar net kortliks gelet word op die metodes van pasiëntesorg wat wel bestaan, sal dit duidelik wees dat daar ook verskeie maniere van evaluering sill wees:

a) Spanverpleging

'n Span van verpleegsters met 'n leier doen alles vir 'n groep pasiënte. Die span het senior lede. junior lede en verpleegassistente. Hulle beraadslaag saanı, deel gedagtes, besluit op die beste vir die pasiënt en as "n span gee hulle die beste vir die pasiënt

\section{b) Multidissiplinêre span}

Hierdie span bestaan uit die geneesheer, die verpleegster, die maatskaplike werker, fisioterapeut, atrbeidsterapeut, dieëtkundige ensomeer en as totale span sal daar verskillende fasette van die pasiënt se behandeling bespreek en toegepas word.

c) Progressiewe verplegingsorg

Dit is die metode waar ' $n$ pasiënt in een of ander afdeling van die hospitaal toegelaat word - afhangende van sy toestand. Hy ontvang gespesialiseerde sorg en as hy in sekere vlak van beterskap bereik gaan hy na 'n ander afdeling. Daar is dus verskillende fases waardeur die pasiënt moet gaan voordat hy ontslaan sal word.

d) Terminale verplegingsorg

Hier bestaan versorging basies uit verligting van pyn en behandeling van simptome. Die pasiënt geniet baie "vryhede" ten opsigte van besoektye, medikasie, dieë ensomeer. Al die behandeling is gerig op die doelwit om die pasiënt so gemaklik te maak as moontlik en so min pyn te laat verduur as moontlik.

e) Funksionele verpleging

Dit is die tipe van verpleging wat taakgerig is. " $n$ Verpleegster verrig "n taak vir al die pasiënte bv. maaltye bedien. bedbad. ens. Afhangende van die stadium van haar opleiding sal sy 'n taak verrig bv. basiese take, tegniese take, administratiewe take ens.

\section{f) Primêre verpleegsorg}

In hierdie geval is die verpleegster vir 24 uur verantwoordelik vir die pasiënt alhoewel sy nie noodwendig aan diens hoef te wees nie. Sy is verantwoordelik vir die beplanning van die totale benadering en versorging van die pasiënt binne die raamwerk van die dokter se voorskrif.

Dit is net " $n$ kort weergawe, maar is nogtans duidelik genoeg om te laat verstaan dat die evaluering van verplegingsorg ' $n$ evalueringsisteem van sy eie sal verg. Evaluering word gedoen in terme van hoe die pasiënt verwag word om te reageer op die beplande behandeling. In die versorgingsprogram van die pasiënt is daar " $n$ hele reeks doelstellings wat voortdurend bereik moet word. Die doel van sekere optredes is om die pasiënt se pyn te verlig. In die toediening van sekere medisyne sal die pasiënt voortdurend dopgehou word vir reaksie in terme van die verwagtinge wat gestel word. Voortdurende evaluering van al die fasette van die pasiënt se toestand en vordering is nodig sodat die verpleegster sal weet of haar diagnose en behandeling nog effektief is sodat die doelwit, nl. gesondheid, bereik kan word. Sommige van die metodes van evaluering kan net kortliks aangestip word:

die skrywe van verslae met die essensiële besonderhede daarin vermeld op so "n wyse dat dit maklik sal wees om te sien of die pasiënt vorder of nie. Grafiekstelling val besonderhede soos gedoen word met koors, bloeddruk en urinetoetse is "n baie effektiewe manier om die toestand van 'n pasiënt vinnig te evalueer.

- in sommige gevalle kan pasiënte onderwerp word aan oefeninge om sodoende te bepaal of hulle vorder. Indien dit 'n persoon is wat bv. weer moet leer loop kan daaglikse aantekeninge omtrent sy bewegings. sy liggaamshouding ensomeer, mettertyd in volledige beeld gee. n Ander metode om pasiënte se vordering te evalueer is deur middel van groepbesprekings deur die multidissiplinêre span. Elkeen lewer 'n bydrae deur te sê wat hy gevind het in verband met die pasiënt se reaksies en sodoende kan daar dan bepaal word wat die vordering is en wat die nuwe behandeling sal wees.

- die pasgenoemde metode word ook deur die verpleegspan as sulks gebruik. Die suster en verpleegsters hou "n samespreking oor die toestand en behandeling van die pasiënt. Alle voorstelle word bespreek en indien daar radikale verandering beoog word, word die dokter geraadpleeg vir sy toestemming en verandering van voorskrifte.

\section{EVALUERING IN SUID-AFRIKA}

Daar is gepoog om met die baie wye en oppervlakkige skets ten opsigte van evaluering aan te toon dat evaluering bestaan en ook nodig is. Die volgende woorde van Bevis onderstreep die belangrikheid van evaluering: (8,p. 155). "Evaluation should not come at the end of things, but rather at the beginning and continue throughout any process. The essence of process itself, the secret ingredient that makes an entity a process in feedback. . "Wanneer daar na evaluering van verpleging in Suid-Afrika op nasionale vlak gekyk word, impliseer dit " $n$ landswye optrede wat al die provinsies en voorlopig ook nog SWA insluit.

Evaluering sal gedoen word vanuit 'n makrovlak. Die makrovlak verteenwoordig die oorkoepelende owerhede terwyl die mikrovlak bestaan uit streeks- en plaaslike owerhede. Nasionale vlak impliseer nie net evaluering op makrovlak nie, maar wel ook mikrovlak aangesien die mikrovlak funksioneer as "n verlengstuk van die makrovlak

Omdat dit evaluering van verpleging is, sal dit die terreine van opvoedkunde, administrasie en pasiëntesorg insluit. Weens die besondere opset van verplegingsdienste in SuidAfrika, sal evaluering deur verskillende mense onderneem word. Daar sal volgens basiese riglyne opgetree word maar optrede sal kom vanuit sentrale owerhede, provinsiale owerhede en plaaslike owerhede. Daar is ook privaatinstellings wat dus op mikrovlak op private vlak evalueer sal word.

Om te evalueer beteken basies om te meet. Dit is baie eenvoudig gestel. Om te kan meet moet daar "n maat wees. Evaluering moet dus gedoen word aan die hand van kriteria. Evaluering volgens daargestelde kriteria sal bepaal of daar op die mees effektiewe wyse na die doelwit beweeg word. Om mee te begin moet daar dus "n duidelik geformuleerde doelwit en beleid wees. In hierdie geval "n doelwit en beleid ten opsigte van verpleging in Suid-Afrika. Dit sal vervat wees in die Wet op Verpleging (Wet nr. 50 van 1978), die Wet op Gesondheid (Wet nr. 63 van 1977), die Regulasies van die Departement van Gesondheid, die Regulasies van die S.A. Raad op Verpleging die Ordonnansies van die onderskeie Provinsiale Administrasies, die Verordeninge van die onderskeie Munisipaliteite en die reëls van die onderskeie instellings. 
Volgens die kriteria wat in bogenoemde vervat is kan daar verwag word dat sekere standaarde in verpleging gehandhaaf sal word. Voortdurende evaluering sal dus aantoon of optredes nog sodanig gerig is dat die verwagte standaarde bereik word. Wanneer omstandighede wissel weens veranderinge in en om die professie en wanneer die behoeftes van die mens verander, sal dit nodig wees om die kriteria aan te pas.

Dit bring mee dat die stelsel van evaluering ook hersien moel word. Soos reeds gemeld. kan verpleging in die drie komponente van administrasie. opvoedkunde en pasiëntesorg verdeel word. Om die bespreking van evaluering te vergemaklik, sal dit afsonderlik onder hierdie hoofde gedoen word:

\section{Oproedkunde}

In opvoedkunde is daar die opvoedkundige terrein sowel as die opvoedkundige administrasieterrein wat elk evalueer moet word.

Evaluering van opvoedkunde beteken dat daar gekyk moet word of die leersituasie van so ' $n$ aard is dat die verwagte standaarde bereik word. Die leersituasie sluit ondermeer in: die "leerling. die leerstof en die leerkrag. " Evaluasie van:

\section{Leerling}

Leerling in hierdie geval is enige persoon wat besig is met studie ongeag of dit basiese opleiding is, of voortgesette opleiding of indiensopleiding. Hoe word 'n leerling op nasionale vlak in Suid-Afrika ge-evalueer?

- vertroulike verslae word geskryf wat 'n indikasie gee van die persoon se hantering van situasies.

- vorderingsverslae word geskryf sodat in bespreking daarvan met die leerling self " $n$ beeld kan gee of die persoon die stadium van optrede bereik het wat nodig is vir verpleging en/of studies behartig kan word.

- onderhoude word met indiwidue gevoer om uit te vind of hulle op die regte tydstip op die regte plek ten opsigte van die professie en die verwagtinge is.

- mense word soms onderwerpe aan stress-situasies om te sien wat hul optrede sal wees. Hulle word voor keuses te staan gebring of in sommige gevalle word mense gevra om probleme op te los.

\section{Leersiof}

Leerstof in hierdie geval sluit al die inhoude van alle leerplanne in. Om "n kriterium daar te stel waarvolgens evaluering gedoen kan word, word alle leerplanne deur die S.A. Raad op Verpleging vrygestel. Evaluering van leerplanne berus op:

- kommentaar ten opsigte van die leerplanne nadat dit vir in tyd op die proef gestel is.

- die hou van samesprekings om die leerplanne te analiseer ten opsigte van die leerinhoud.

- kommentaar en besprekings ten opsigte van die voorgestelde handboeke wat gebruik is.

- die analisering van uitslae van eksamens wat op nasionale vlak geskryf is. Daar moet dan verder ondersoek ingestel word na die samestelling van die leerplan. As uitslae swak is in Vak A bv. kan die fout lê by:

- handboeke wat voorgeskryf is

- kwalifikasies van leerkragte

- samestelling van leerplan in sy geheel, met ander woorde vak A is relat ief ongekompliseerd, mar dit is baie omvangryk en word gedoseer saam met verskeie ander omvangryke vakke. Die tydfaktor is dus belangrik.
- die analisering van vraelyste deur leerlinge ingevul en ander deur leerkragte ingevul, kan ook dien as 'n evalueringsmetode

- leerstof sluit ook die data ten opsigte van kliniese praktika in. Evaluering van praktika berus ook op uitslae van toetsings. (deurlopende toetsings) die gehalte van pasiëntesorg wat verleen is, die gehalte van bystand aan mediese en paramediese personeel en die evaluering van die leerling se optrede tydens in toetsing sowel as andersins.

\section{Leerkragte}

Met leerkragte word bedoel alle indiwidue wat op een of ander manier op een of ander tydstip deel het aan onderrig van ' $\mathrm{n}$ ander indiwidu. Evaluering van hierdie persone geskied meestal verkeerdelik volgens die uitslae wat hul leerlinge bereik. Die leerkragte word evalueer op grond van:

- hantering van die leersituasie.

- hulp in totaliteit aan die leerling.

- organisering van die leersituasie en fasiliteite vir die leersituasie.

- ontleding en inwerkingstelling van die leerplan.

- deelname aan besprekings en bydrae tot bevordering van die opvoedkunde in verpleging.

- motivering van kollegas en leerlinge ten opsigte van die professie

- verslae geskryf oor die leerkrag.

- onderhoude gevoer met die leerkrag.

- inspeksie gedoen ten opsigte van metodes, hulpmiddels, rekordhouding ens.

\section{Opvoedkundige administrasie}

Evaluering van opvoedkundige administrasie beteken dat daar gekyk moet word na die leerfasiliteite en organisering. Dit word gedoen aan die hand van vereistes wat daargestel word deur die S.A. Raad op Verpleging. Om te evalueer of dit volgens standaard gedoen word, kan gelet word op:

- die skakeling wat daar is tussen 'n instelling en die S.A.R.V.

- die nakoming van die vereistes van die S.A.R.V.ten opsigte van vorms en rekords

- die verskaffing van fisiese fasiliteite soos dit vereis word deur die S.A.R.V

- die nakoming van opleidingsvereistes ten opsigte van teorie sowel as praktyk.

- die fasiliteite beskikbaar in die gemeenskap wat gebruik kan word ten opsigte van opleiding.

Daar word verslae verwag van die instellings ten opsigte van opleiding wat na die S.A.R.V. sowel as na die Provinsiale Administrasie en Staatsgesondheid (afhangende van die verdeling) moet gaan.

Daar word inspeksies gedoen deur die S.A.R.V. sowel as deur Provinsiale Administrasies en Staatsgesondheid.

Daar kan ondersoeke geloots word indien daar klagtes of ongeruimdhede is. Die ondersoek is dan "n metode van evaluering van die situasie.

Uitslae van eksamens of menings van personeel in verband met sekere sake kan dien as rede vir evaluering van 'n situasie in die instelling.

Om opvoedkunde te evalueer beteken om al die terreine waar opvoedkunde plaasvind te evalueer. Dit sal dus die hospitaal sowel as die kollege en die gemeenskap insluit. Inspeksies, ondersoeke en verslae kan dus op al die terreine verwag word en kom van sentrale, provinsiale of plaaslike vlak. 


\section{Administrasie}

Die terrein van administrasie sluit organisering, beheer, metodes en prosedures, personeel, finansies en beleid in. Daar is Administrasie op Sentrale, Provinsiale en Plaaslike vlakke. Die suksesvolle administrering van verpleging verseker hoë standaarde soos wat verwag word volgens die kriteria wat daargestel is. Evaluering van administrasie kan onderneem word deur inspeksies deur die S.A. Raad op Verpleging, die provinsiale administrasies, die sentrale owerhede en ook deur die plaaslike owerhede. Daar kan ook gesteun word op verslae, rekords en ondersoeke wat ingestel kan word in antwoord op ongerymdhede. Die stiptelike nakom van reëls en regulasies en die logiese verloop van organisering dui gewoonlik op 'n gunstige uitslag ten opsigte van evaluering. ' $n$ Spesifieke instelling wat absoluut volgens daargestelde vereistes funksioneer sal nogtans ook die waarde-oortuigings van die gemeenskap in ag moet neem en ook moet deelneem aan navorsing en eksperimentering binne die raamwerk van die kriteria.

Verslae, rekords en ondersoeke wat gedoen kan word is reeds tot 'n groot mate genoem. Die evaluering van die administrasie van verpleging kan effektief gedoen word deur werkstudiepersoneel indien dıt op die korrekte wyse aangepak word. Werkstudiepersoneel funksioneer gewoonlik vanuit die Staatsdienskommissie of vanuit die Hoofkantoor van die Provinsiale Administrasie se Hospitaaldienste.

\section{Pasiëntesorg}

Die terrein van pasiëntesorg is baie wyd aangesien dit nou gemeenskapsgeoriënteerd is. Evaluering van die terrein van pasiëntesorg is nogtans noodsaaklik. Evaluering kan soos volg aangepak word:

- werkstudieontleding van personeel en prosedures.

- ontleding van die gehalte van sorg deur inspeksies te doen.

- ondersoeke doen na aangeleenthede wat gerapporteer word.

- ontleding van verslae en statistieke wat deur instellings gestuur word na die S.A.R. op V. sowel as aan die Provinsiale Administrasie (Hoofverplegingsbeamptes).

- ontleding van die tipe rekords wat gehou word sover dit die betrokke tipes van inligting van pasiënte aangaan.

- ondersoek na die effektiwiteit van toesighouding tydens die versorging van pasiënte.

- bepaling van die mate wat die teorie korreleer met die praktyk en ook bepaling van die mate wat die pasiënt as totaliteit gesien en behandel word met inagneming van sy familie en omgewing.

- observasie wat gedoen kan word ten opsigte van die verloop van die daaglikse roetine.

onderhoude met die pasiënte en/of met naasbestaandes en ook met lede van die algemene publiek aangaande hul siening omtrent die versorging wat hulle kry, gekry het en graag sou wou ontvang.
- verpleegoudit.

Soos wat evaluering pas geskets is vir die drie komponente van verpleging, kan dit op makro sowel as mikrovlak onderneem word. Die belangrike feit is dat daar wel te alle tye een of ander vorm (afhangende van die aard van verpleging) van evaluering moet wees sodat daar vootdurend verseker kan wees dat die verpleging nog streef na die handhawing van die hoogste moontlike standaarde.

\section{SLOT}

Dit is duidelik en aanvaarbaar dat daar in stelsel van evaluering in enige instelling sal wees

Dit is egter belangrik om te onthou dat evaluering nutteloos sal wees indien dit nie volg op deeglike beplanning nie. Beplanning gee rigting en sekuriteit vir optrede. Deel van die beplanning is om "n baie deeglik geformuleerde doelwit na te streef. Sodra daar "n doelwit is om na te streef is dit logies as daar gepoog word om dit na die beste van die vermoeë na te streef. Die beste van enige persoon is egter ' $n$ vae begrip indien dit nie volgens definitiewe kriteria gemeet kan word nie. 'n Doelwit omlyn dus onmiddellik ook sekere reëls vir optrede. Om sukses te behaal moet reëls nagekom word en om te weet tot watter mate die beoogde sukses behaal is. is dit nodig om 'n program van evaluering te beplan reg aan die begin van die beplanning van al die verwagte optredes.

Dit is dan in verpleging ook so dat wanneer daar beplan word om 'n spesifieke prosedure bv, in te stel dat deel van die aanvanklike beplanning ook ruimte sal afstaan vir die voortdurende toetsing van die effektiwiteit van daardie prosedure na die hand van vooropgestelde doelwitte wat bereik wi word met die betrokke prosedure. Hierdie doelwitte sal dan dien as die daargestelde kriteria vir evaluering.

re. Hierj-die doelwitte sal dan dien as die daargestelde kriteria vir evaluering.

\section{BIBLIOGRAFIE}

1. Popiel, Elda, S. Nursing and the process of cominuing education, (Mosby Co. 1973)

2. Yura, Welsh: The nursing process, assessing, planning, implementing, evaluat ing, (ACC. 1973)

3. Rines. Alice R. : Evaluating student progress in learning the pracrice of nursing (Teachers College Columbia University. 1974)

4tevens, B.J.: The Nurse as executive, (Contemporary Publishing INC, Wakefie B... Th,

5. Tracey, W.R.: Evaluating, training and development systems, (AMA, 3rd print ing)

6. Dressel, P.L.: Evaluation in Higher Education, (Houthton Mifflin Co., Boston 1961)

. Eckelberry, G.K.: Administration of comprehensive nursing care - the nature of professional practice, (ACC. 1971)

8. Bevis, E.O.: Curriculum building in nursing - a process, (Mosby Co. 1973) 